\title{
More Nutrients and More Hazards When Using Poultry Litter in Plant and/or Animal Nutrition
}

\author{
Saad M Magdy* \\ Department of Food Safety \& Contamination, Egypt
}

Submission: November 01, 2017; Published: December 11, 2017

*Corresponding author: Saad M Magdy, Department of Food Safety \& Contamination, Egypt, Email: madgdy_saad6@yahoo.com

Abstract

Poultry litter is an organic, mixture of feces, wasted feeds, bedding materials and some feathers. So, it's still valuable fertilizer resource needed in many agricultural areas. An alternative uses for almost $50 \%$ of the litter generated in concentrated production farms are directed to feed small and large ruminants. Undoubtedly, poultry litter had high nutritive value to both plant and animal, while it simultaneously contains wide range of both biological and chemical hazards. Clear understanding of the hazard(s) cycle and pathway in environment are essential requirements for establishing effective control strategies to prevent or reduce the adverse effects on agriculture, environment, food safety and public health.

\section{Introduction}

Lacking of organic substances, especially in new reclaimed sandy soil and the high nutritive value of poultry litter leads to recommend the usage of such waste as fertilizer of choice. Average nutritive value of poultry litter as fertilizer, calculated as N, P, and $\mathrm{K}$ is $3.1,0.5$ and $2.8 \%$, respectively. As well, the poultry ashes contain the 4 main requirements of $\mathrm{Cu}$, Fe, Mn and Zn at concentrations of 332, 195, 277 and 252ppm, respectively [1]. Poultry litter is commonly recycled into the soil to enhance both structure and fertility of agricultural land, especially the new reclaimed sandy soil. Poultry litter contains significant amounts of nitrogen due to the presence of high levels of bio available protein and amino acids [2].

\section{Poultry Litter as Plant Fertilizer and Enhancer (Table} 1)

Recently, there have been some food safety and human health issues associated with the usage of poultry litter. Poultry litter as an important source of nutrients for many edible crops, may also contain some biological hazards that can threaten human health [4]. Poultry litter could be a source of human pathogens such as Salmonella, Campylobacter and Listeria that can potentially contaminate both edible crops and environment, which consequently leads to food-borne diseases $[5,6]$. Poultry litter contains wide and diverse counts of microorganism including both of gram positive and negative bacteria. Surveillance data from USA and Canada showed that the hazards of Salmonella, E.coli, Campylobacter and Listeria are the most responsible pathogens due to usage of poultry litter [7]. Poultry wastes are commonly composting prior to application in order to control the biological hazards in the end

recycled product. Many studies showed that some pathogenic cells remained persisting the finished compost [8]. As well, during composting there is a high significant possibility for some pathogens re-growth including the survived small population of pathogen and the transferred ones from the environment? A wide range of biological hazards were reported in poultry litter and wastes including Actinobacillus, Bordetella, Campylobacter, Clostridium, Corynebacterium, Escherichia coli, Globicatella, Listeria, Mycobacterium, Salmonella, Staphylococcus and Streptococcus [1,9-11].

Table 1: Some poultry litter wastes and nutrients content. National Resource, Agriculture and Engineering Service [3]

\begin{tabular}{|c|c|c|c|c|}
\hline \%Component & $\begin{array}{c}\text { Broiler } \\
\text { Litter }\end{array}$ & $\begin{array}{c}\text { Broiler } \\
\text { Cake }\end{array}$ & $\begin{array}{c}\text { Roasted } \\
\text { lit. }\end{array}$ & $\begin{array}{c}\text { Breeder } \\
\text { Lit. }\end{array}$ \\
\hline Moisture & 21.5 & 40 & 22.5 & 33.5 \\
\hline Total solids & 87.5 & 60 & 77.5 & 66.5 \\
\hline Total-N(Lb/T) & 72 & 46 & 71 & 34 \\
\hline P205 & 69 & 53 & 72 & 56 \\
\hline $\mathrm{K} 20$ & 46 & 36 & 46 & 33 \\
\hline $\mathrm{Ca}$ & 44 & 34 & 42 & 89 \\
\hline $\mathrm{Mg}$ & 8 & 7 & 9 & 7 \\
\hline$S$ & 12 & 9 & 14 & 8 \\
\hline \multicolumn{2}{|c|}{ (Zn-Cu-Mn) } & $\left(\begin{array}{lll}0.2 & 0.7\end{array}\right)$ & & \\
\hline
\end{tabular}

It's worthy to mention that both quality and quantity of biological hazards are affected by many variables including, 
not limiting to, the pathogen specie and serotype, poultry specie and age, season and farm management practices [12]. As an example, fecal samples of 18 week old layers had a significant prevalence of Salmonella (55\%), the decreased by aging to reach $(41 \%)$ at 25-28 weeks, then (5.5\%) at 66-74 weeks old. Also, the prevalence of Salmonella in floor litter of broilers was significantly related to age of the flock and the geographical region in which the flocks were housed [7]. Recently, it's well known that Salmonella sp. is the most common biological hazard in poultry litter [13]. Survey studies extended for 10 years on food-borne disease outbreaks caused by Salmonella showed that, Salmonella are commonly associated with 24 - 30\% of poultry meat products and eggs, respectively [14]. Chicken egg could be salmonella-contaminated horizontally or vertically. Horizontal transmission occurred as a result to fecal contact, while vertical one is due to infected ovaries or eggs [15].

In poultry industry, especially in farms of broilers and table eggs the management systems are mainly depending upon prophylaxis management practices. So, the flocks are routinely exposed to different kinds of antibiotics. Consequently, the great amounts of chicken litter and the widespread usage might accompany by widespread antibiotic- resistant bacteria contaminating the environment [4]. Antibiotic-resistant bacteria could be transferred either vertically or horizontally. The routine use of antibiotics as prophylaxis and/or growth promoter enhances the selectivity of antibiotic-resistant bacteria inside the gastrointestinal tract which excreted and applied to the agricultural lands [16]. The increased and repeated usage of antibiotics in poultry industry introduces more selective pressure resulting the development of multiresistance characteristics in certain bacterial populations It's important to identify and characterize different isolated antibiotic-resistant bacteria of poultry litter to predict their pathogenicity and their persistence in environment [17].

\section{Poultry Litter as Feed Component for Farm Ruminants}

Also, poultry litter is used in many countries as feed ingredient for farm ruminants, as low cost feed ingredient (Table 2)

Table 2: Proximate analysis and nutritive value of poultry wastes. Roothaert et al. [18]

\begin{tabular}{|c|c|c|c|c|}
\hline Poultry Waste & \% DM & \% CP & \% CF & \%Ash \\
\hline Poultry litter & 84.7 & 31.3 & 16.8 & 15 \\
\hline Broiler litter "Rhodes" & 86.5 & 19.5 & 14.4 & 13.1 \\
\hline $\begin{array}{c}\text { Broiler litter } \\
\text { "sawdust" }\end{array}$ & 87.5 & 25.5 & 17.7 & 15.6 \\
\hline Layer manure dried & 89.7 & 28 & 12.7 & 28 \\
\hline
\end{tabular}


recent strategies of disinfection are required depending upon combinations between more than one technique to eliminate or potentiate the biological hazards, especially those of stressadaptation. Usually composting is employed as the first step in most strategies of multi-step treatment systems, because composting is efficient enough to get rid of large populations of biological hazards $[25,26]$. Additional physical, chemical and/ or biological treatments might lead to further elimination of the remaining survive cells. The multiple treatment systems might be efficient in reducing and elimination biological hazards from poultry litter, only when proper control measures were applied [19,27].

\section{Mobilization of Hazards in Agriculture Environment}

$\backslash$ Poultry litter as natural nutritive resource is intentionally applied to arable agriculture lands to improve both structure and fertility of the soil. Poultry litter which is composting improperly might carry some food-borne hazards which have the potentiality to survive and/or re-grow to high level of populations under certain environmental conditions [28]. As well, some microbial strains could be acclimatized and adapted to environment during composting processes $[12,13,29]$. Poultry litter as a mixture of different media involving feces, bedding materials, wasted feeds and feathers, represent favorable media for wide range of biological and chemical hazards. Such biological hazards include many food-borne pathogens like Salmonella, Campylobacter, Listeria, Actinomycets, Escherichia coli and Clostridium at high concentrations could reach up to $\llbracket 10^{\wedge} 10 \mathrm{CFU} / \mathrm{gram}$ of poultry litter $[1,10,30]$. The remaining high levels of populations might display different metabolic pathways and interfered with the environmental micro flora. It's worthy to mention that the most potent biological hazards are the antibiotic-resistant bacteria and stress adapted pathogens which previously exposed to low doses of antibiotics and/or unfavorable processing treatments $[15,28]$. The vertical and horizontal mobilization of such resistant microbes could threaten human, animal and public health, especially when those fatal hazards had the capability to break through food chain. As well, bacterial antibiotic resistance may be induced in animal guts that previously exposed to poultry litter either when they ingest feeds containing poultry litter or when they were grazed on contaminated arable lands [31-33].

\section{Transformation of Antibiotic Residues to Edible Plant Tissues}

Antibiotics are commonly administered to poultry feed, besides the great amounts used in the prophylaxis management systems. Most of the oral applied antibiotics are poorly absorbed in the poultry gut, and then consequently those large amounts of antibiotics were excreted in feces and urine "manure". Approximately $90 \%$ of the applied antibiotics might be excreted as the parent compound(s) [34]. The most common antibiotics present in poultry litter are bactracin, chlortetracycline, monesin, tylosin, penicillin, chloramphenicol and virginiamycin [5,35]. Quantitatively, antibiotic residues in poultry litter showed varied range between neglible traces up to $216 \mathrm{mg} / \mathrm{kg}$ of the dried poultry litter [5].

Undoubtedly, there is an expected risk when using poultry litter in either plant or animal nutrition due to the mechanisms of uptake and accumulation of certain hazards in edible tissues of exposed plants and animals. The most common observed chemical hazards were antibiotic residues [4]. In general, the uptake of pharmaceuticals is depending upon the physical and chemical properties of the parent drug or its degraded products. So, it's very important to define whether a chemical is neutral or ionized at the natural environmental media $\mathrm{pH}$ values. Thu, there are separate models exist to predict uptake of chemicals in different forms. For neutral chemicals, hydrophobicity is proposed to be the most incorporated factor affecting the uptake of chemicals from soil to plant edible tissues [36]. Regarding the usage of poultry litter as feed component for ruminants, the risk assessment of antibiotic residues should be determined considering many factors including, not limited to, the nature and stability of the chemical, the pattern and metabolic pathways inside the ruminant's body, the targeted organs and the excreted, secreted and accumulated pattern $[33,37,38]$.

Recently, the World Health Organization (WHO, 2014) issued a list of important antibiotics to human medicine contains 32 drug classes with 260 individual drug. Out of the listed 260 drugs, 39 are recommended and commonly prescribed for use in farm animals. The 39 antibiotics used in veterinary medicine are distributed between prophylaxes, curatives and feed additives. It's not easy to determine which veterinary antibiotics have undesired significant effects on human health. It's worthy to mention that the antibiotics available for use in animal agriculture are varied from one country to another. So, the available data concerning some developed countries are not necessarily representing other countries. For accurate evaluation or to determine the effective agriculture antibiotics having impact clinical outcomes, there is a need for true data about; pathogen's ecology as well as data dealing the priotrized list of bacteria posing antibiotic resistance [13][39]. However, accurate disinfection strategies should be carefully established to avoid biological and chemical contamination during poultry litter composting. Multi-step treatment in combination with composting, as first step, is preferred to get rid of large population of pathogens [19]. Treatment techniques should include certain parameters including indicator microbes and certain chemicals to evaluate the efficacy and validity of the applied techniques $[27,40,41,42]$.

\section{Conclusion}

Expansion in poultry industry resulted an increased yield of poultry litter wastes which might threaten public health. Recycling of such wastes is recommended and applied 
in many countries due to the potential nutrients which are required for plant and animal nutrition. In both developed and developing countries the usage of poultry wastes is allowed to enhance structure and fertility of arable soils. Moreover, many countries including Egypt approved the usage of poultry litter as feed component which could be admitted to farm ruminants. Recycling of poultry litter had many environmental, economic and nutritional advantages. In most countries permitted the usage of poultry litter in agriculture, there are rigid rules and specifications should be followed before application. The adopted criteria aiming to ensure that the recycled product is free from biological hazards especially the pathogens. Actually, most of the potential biological hazards could be controlled when applying efficient composting physical, chemical and biological treatment systems. Meanwhile, there is still a problem due to the contamination of the treated wastes with antibiotic-resistant bacteria and stress-adapted pathogens. Moreover the chemical hazard of high concentrations of antibiotic residues could potentiate dramatic effects, especially when introduced to food chain. So, accurate and efficient strategies are urgently needed to control either biological or chemical hazards, especially that of stress-adapted pathogens and antibiotic residues.

\section{References}

1. Bolan N, Szogi A, Chuasavathi T, Seshadri B, Rothrock M, et al. (2010) Use and management of poultry litter. World's Poult.Sci J 66: 673-698.

2. Talaro K, Talaro A (2002) Physical and chemical control of Microbes Foundations in Microbiology, (4 ${ }^{\text {th }}$ edn), The McGraw-Hill Companies, New York, USA pp: 325-327.

3. National Resource, Agriculture \& Engineering Service "NRAES" (1999) Poultry wastes management handbook, NRAES-132 - Riley-Robb Hall, Ithaca, NewYork, USA.

4. Saad MM (2016) The risk of human exposure to antibiotic Residues from food of both animal and plant origin. EJBPS 3(5): 12-15.

5. Chinivasagam HN, Redding M, Runge G, Blackall PJ (2010) Presence And incidence of food borne pathogens in Australian chicken litter $\mathrm{Br}$ Poult Sci 51(3): 311-318.

6. Wilkinson K, Tee E, Tomkins R, Hepworth G, Premier R (2011) Effect of heating and aging of poultry litter on the persistence of Enteric bacteria. Poult.Sci 90(1): 10-18.

7. Renwick SA, Irwin RJ, Clarke RC, McNab WB, Poppe C, et al. (1992) Epidemiological associations between characteristics of Registered broiler chicken flocks in Canada and the salmonella Culture status of floor litter and drinking water. Can Vet J 33(7): 449-458.

8. Shepherd M, Liang P, Jiang X, Doyle M, Erickson MC (2007) Fate of Escherichia coli during on-farm dairy manure-based composting. JFood Prot 70(12): 2708-2716.

9. Lovett J, Messer JW, Read RB (1971) The micro flora of southern Ohio poultry litter. Poult.Sci.J., 50(3): 746-751.

10. Lu J, Sanchez S, Hofacre C, Maurer JJ, Harmon BG, et al. (2003) Evaluation of broiler litter with reference to the microbial compoSition as assessed by using S-16 r RNA and functional gene markers Appl Environm Microbiol 69(2): 901-908.

11. Ngodigha E, Owen O (2009) Evaluation of the bacteriological characteristics of poultry litter as feedstuff for cattle. Sci Res 4(3): 188190.
12. Li X, Payne JB, Santos FB, Levine JF, Anderson KE, at al. (2007) Salmonella populations and prevalence of layer feces from comm. Ercial high-rise houses and characterization of the salmonealla Isolates by serotyping, antibiotic resistance analysis and pulsed Field gel electrophoresis. Poult Sci J 86(3): 591-597.

13. Centers for Disease Control and Prevention "CDC" (2013) Surveillance For food-borne disease outbreaks - United States “1998-2008”, Morbid Mortal Weekly Report (MMWR) 62: 1-34.

14. Centers for Disease Control and Prevention "CDC" (2013) Surveillance For food-borne disease outbreaks -US 2009-2010, Morbid Mortal Weekly Report (MMWR) 63: 41-47.

15. Foley SL, Nayak R, Hanning IB, Johnson TJ, Han J, et al. (2014) Population dynamics of Salmonella enteric syrotypes in comercial egg and poultry production. Agriculture 4: 23-25.

16. Levy SB (1992) The antibiotic paradox: How miracle drugs are destroying the miracle, Plenum Publisher, New York, USA.

17. Khan A, Nawaz M, Khan S, Steele R (2002) Detection and Characterization of erythromycin-resistant methylase genes in Grampositive bacteria isolated from poultry litter. Appl Microb Biotechnol 59(2-3): 377-381.

18. Roothaert L, Malthewman (1992) Poultry wastes as foods for Ruminants and associated aspects of animal welfare. AJAS 5(4): 593606.

19. US-Department of Agriculture “USDA" (2000) Environmental engineering, National Eng. Handbook, Chapter 2 Part 637 "composting” USDA, Washington DC, USA.

20. Pugh D, Wenzel J, D’Andrea G (1994) A survey on the incidence of disease in cattle fed broiler litter. Vet Med 89: 665-667.

21. Berry ED, Woodbury BL, Nienaber JA, Eigenberg RA, Thurston JA, et al. (2007) Incidence and persistence of zoonotic bacteria And protozoan pathogens in a beef cattle feedlot runoff control Vegetative treatment system. J Environm Qual 36(6): 1873-1882.

22. Kelleher BP, Leahy JJ, Henihan AM, O’Dwyer TF, Sutton D et al. (2002) Advances in poultry litter disposal technology. Review Bio-Source Technol 83(1): 27-36.

23. Shepherd MW, Liang P, Jiang X, Doyle MP, Erickson MC (2010) Microbiological analysis of compost produced on South Carolina poultry farms. Appl Microbiol 108(6): 7067-7076.

24. Nandi S, Maurer JJ, Hofacre C, Summers AO (2004) Gram positive Bacteria are a major reservoir of class-1 antibiotic resistance integRons in poultry litter. Proc Nat Acad Sci USA 101(18): 7118-7122.

25. Jeffrey JS, Kirk JH, Atwill ER, Cullor JS (1998) Prevalence of selected Microbial pathogens in processed poultry waste used as dairy Cattle feed. Poult Sci 77(6): 808-811.

26. Bernal M, Alburqerque J, Moral R (2009) Composting of animal Manures and chemical criteria for compost maturity assessment. A review Bioresour Technol 100(22): 5444-5453.

27. US-Food and Drug Administration "USFDA" (2006) National Organic Standards Board Crops Committee Recommendations for guid. Use of compost, USA.

28. Chander Y, Goyal S, Gupta S (2006) Antimicrobial resistance of Providencia spp. Isolated from animal manure. Vet J 172(1): 188-191.

29. Higgins R, Malo R, Rene-Roberge E,Gauthier R (1982) Studies on the dissemination of Salmonella in nine broiler-Chicken flocks. Avian Dis 26: 26-33.

30. Stern N, Robach M (2003) Enumeration of Campylobacter sp. In Broiler feces and in corresponding processes caracasses. J Food Prot 66(9): 1557-1563.

31. Guan J, Spencer J, Sampath M, Devenish J (2004) The fate of Genetically modified Pseudomonas strain and its transgene During the composting 
of poultry manure. Can JMicrobiol 50(6): 415-421.

32. Graham JP, Evans SL, Price LB, Silbergeld EK (2009) Fate of antimicrobial-resistant Enterococci and staphylococci and resistance determinants in stored poultry litter. Environ Res 109(6): 682-689.

33. Wesche AM, Gurtler JB, Marks BP, Ryser ET (2009) Sub lethal injury Resuscitation and virulence of bacterial food-borne pathogens. JFood Prtect 73: 1121-1138.

34. Kumar K, Gupta SC, Baidoo SK, Chander Y, Rosen CJ (2005) Antibiotic uptake by plants from soil fertilized with animal manure. J Environm Qual 34(6): 2082-2085

35. Barbour E, Husseine S, Farran M, Itani D, Houala R, et al. (2002) Soil solarization: A sustainable agriculture approach to Reduce microorganisms in chicken manure treated soil. J Sust Agric 19(4): 95104.

36. Carter LJ, Harris E, Williams M, Ryan JJ, Kookana RS, et al. (2014) Fate and uptake of pharmaceuticals in soil plant System. J Agric Food Chem 62(4): 816-825

37. Messer JW, Lovett J, Murthy GK, Wehby AJ, Schafer ML (1971) Assessment of some public health problems resulting from feeding poultry litter to animals. Poult Sci J 50(3): 874-881.

38. Yousef A, Courtney P (2003) Basics of stress adaptation and implications in new generation foods. In Microbial stress adaptation and food safey, CRC Press: Boca Raton, Florida, USA, pp: 1-30.

39. National Organic Standards Board "NOS" (2006) Crops Committee Recommendation for guidance use of compost, vermicompost, processed manure and composr teas. Nat Organic Standards Board, Washington DC, USA.

40. Forsythe R, Ross W, Ayers J (1967) Salmonella recovery following Gastrointestinal and ovarian inoculation in the domestic fowl. Poult Sci 46(4): 849-855.

\section{Your next submission with Juniper Publishers will reach you the below assets}

- Quality Editorial service

- Swift Peer Review

- Reprints availability

- E-prints Service

- Manuscript Podcast for convenient understanding

- Global attainment for your research

- Manuscript accessibility in different formats

( Pdf, E-pub, Full Text, Audio)

- Unceasing customer service

Track the below URL for one-step submission https://juniperpublishers.com/online-submission.php 